\title{
Erradicação da doença de Aujeszky em Santa Catarina: importância da condição sanitária das leitoas de reposição
}

\author{
Aujeszky's diasease eradication in Santa Catarina State: relevance of sanitary status of \\ replacement gilts
}

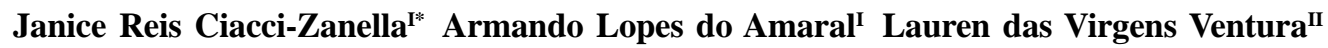 \\ Nelson Morés ${ }^{\mathrm{I}}$ Hélio Bortoluzzi ${ }^{\mathrm{II}}$
}

\section{RESUMO}

A doença de Aujeszky (DA) é uma infecção causada por um herpesvírus, o vírus da DA (VDA), primariamente em suínos. Esta doença está presente no Estado de Santa Catarina (SC) desde 1984. Devido ao impacto da DA no mercado exportador de carne suína, no comércio de reprodutores e nas perdas de produtividade, um programa de erradicação, financiado por uma parceria entre a indústria e a associação de produtores tem tido sucesso em eliminar gradualmente a DA de rebanhos suínos de SC. O último caso de DA no estado foi identificado em julho de 2004. Durante o processo de despovoamento/repovoamento, foi detectado um rebanho suíno positivo para o VDA localizado no oeste de SC. Estudos de rastreabilidade da origem daqueles animais indicaram que a fonte era uma granja que distribuía reprodutores ilegalmente sem certificação sanitária. Este suinocultor mantinha um sistema de integração que incluía 40 diferentes produtores para quem eram comercializados reprodutores elou suínos para terminação. Testes de soroprevalência detectaram anticorpos anti-VDA em 12 daqueles rebanhos. Devido a sua localização dentro do raio de $2,5 \mathrm{~km}$ do foco inicial, uma outra granja, onde havia uma central de inseminação artificial que distribuía sêmen suíno para outras 5 granjas do mesmo proprietário, foi testada e também resultou positiva. Os objetivos deste artigo são descrever as condições sanitárias frente ao VDA naquelas granjas que receberam suínos ou sêmen suíno daqueles suinocultores, as medidas para controlar e eliminar o VDA dos rebanhos positivos e a situação atual decorrente deste trabalho. Além disso, o artigo busca alertar que medidas de vigilância ativa e normas sanitárias para comércio e distribuição de material genético devem ser seguidas, caso contrário, a DA pode recrudescer e tornar-se fora de controle como ocorria antes do início deste programa.

Palavras-chave: Aujeszky, vírus, suíno, erradicação, reposição, Santa Catarina.

\section{ABSTRACT}

Aujeszky's disease $(A D)$ is an herpesvirus infection, caused by the pseudorabies virus (PRV), primarily in swine and present in Santa Catarina State (SC) since 1984. Due to the impacts of $A D$ in the pork export, breeder's trade and productivity losses, an eradication program, financed by industry and swine producers association, has successfully eradicated the $A D$ of swine herds in SC State. The last case of $A D$ in the State was identified in July of 2004. During the depopulation/repopulation process, a PRV positive swine herd located in the west region of SC State was detected. Traceability studies of the origin of those animals indicated that the source was a swine farm which illegally distributed breeders without sanitary certification. This swine producer maintained an integration system which included 40 different producers, to whom were commercialized breeders and/or finishers. Serumprevalence tests detected PRV antibodies in 12 of those herds. Due to the location into the $2.5 \mathrm{~km}$ of radius from the initial outbreak, another swine farm, which had an artificial insemination center that distributed swine semen to another 5 herds of the same owner was tested positive as well. The objectives of this paper are to describe the sanitary status related to $A D$ on the farms which have received pigs or swine semen from these swine producers, the measures to control and eliminate $A D V$ from positive herds and the outcome of this work. Beyond that, to alert that measures of active surveillance and sanitary rules for commerce and distribution of genetic materials must be properly fulfilled, otherwise, $A D$ can reactivate and become out of control as occurred before the eradication program.

Key words: Aujeszky, virus, swine, eradication, replacement, Santa Catarina.

'Laboratório de Sanidade, Embrapa Suínos e Aves, 89700-000, Concórdia, SC, Brasil. Email: janice@cnpsa.embrapa.br. *Autor para correspondência.

"Associação Catarinense dos Criadores de Suínos (ACCS), Associação das Indústrias da Carne de Santa Catarina (AINCADESC), Embrapa Suínos e Aves, Concórdia, SC, Brasil.

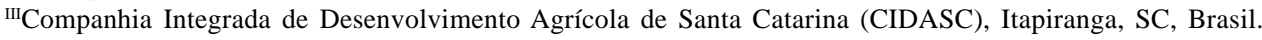




\section{INTRODUÇÃO}

A doença de Aujeszky (DA) é uma doença infecciosa de suínos que traz prejuízos ao setor produtivo, ao mercado de reprodutores e à exportação (KLUGE et al., 1992; METTENLEITER, 2000). As granjas registradas com diagnóstico da infecção perdem a certificação para a venda de reprodutores e de material genético (sêmen e embriões), baseados na Instrução Normativa Número 19 (IN-19) do Ministério da Agricultura Pecuária e Abastecimento (MAPA). Além disso, DA impõe restrições às exportações (ZANELLA, 2002). A DA está listada no Código Zoosanitário da OIE(ORGANIZAÇÃO INTERNACIONAL DE SAÚDE ANIMAL, 2006), como de notificação compulsória.

A DA é causada pela infecção pelo vírus da doença de Aujeszky (VDA) ou vírus da "pseudo-raiva” (PRV), que pertence à família Herpesviridae, subfamília Alphaherpesvirinae. Uma das principais características dos alfaherpesvírus é a habilidade de estabelecer infecções latentes no hospedeiro (ROIZMAN, 1990; METTENLEITER, 2000). Esta habilidade dos herpesvírus em estabelecer e reativar a latência constitui-se no ponto-chave da epidemiologia dessas infecções e tem sido o maior obstáculo para o estabelecimento de medidas de controle e erradicação da doença (VAN OIRSCHOT et al., 1990). Em 2001 foi estimado um prejuízo para o setor suinícola de Santa Catarina de R\$ 931.224,00 ao ano devido à DA, desconsiderando-se o impacto negativo sobre o comércio de reprodutores e o mercado exportador (ZANELLA et al., 2001). Por essa razão, a Embrapa Suínos e Aves, em parceria com produtores e outras instituições ligadas à suinocultura, iniciou, em 2001, um programa de erradicação da DA no Estado (MORÉS \& ZANELLA, 2003). Foram incluídas no programa 985 granjas no Estado, destas 81 erradicaram o VDA por sorologia e vacinação (teste/eliminação de positivos), e 239 despovoaram com eliminação total do plantel. Atualmente o programa encontra-se em fase final de erradicação com mais de $95 \%$ dos rebanhos saneados, estando o restante sob monitoria (MORÉS et al., 2005). Esta fase final caracteriza-se por vigilância e rastreabilidade por meio de sorologia de rebanhos repovoados e de rebanhos suspeitos, além da monitoria daqueles em estágio de erradicação por sorologia.

No processo de despovoamento e repovoamento previsto no programa de erradicação, todos os plantéis repovoados são testados por sorologia para verificação da eficiência do processo e para certificação de que essas granjas foram povoadas com suínos livres da infecção pelo VDA (VAN OIRSCHOT et al. 1990; MORÉS \& ZANELLA, 2003). Neste processo, detectou-se um plantel com suínos sorologicamente positivos no extremo oeste catarinense. No estudo de rastreabilidade destes animais, foi constatado que aqueles positivos foram adquiridos de um mini-integrador sem certificação sanitária que distribuía ilegalmente leitoas e leitões com finalidade de terminação para 40 integrados.

O objetivo deste trabalho é descrever a situação sanitária para o VDA nessas granjas que receberam suínos do referido mini-integrador. Além disso, objetiva-se alertar que medidas de vigilância devem ser ativas neste período de controle e erradicação da DA no estado de SC, pois, se a IN-19 do MAPA que estabelece as normas sanitárias para comércio e distribuição de material genético não for devidamente cumprida, a DA pode recrudescer e tornarse fora de controle como ocorria antes do início deste programa.

\section{MATERIAL E MÉTODOS}

Os soros de suínos vacinados foram testados com o teste de Elisa diferencial para anticorpos antiglicoproteína E ou gE (HerdChek Anti-PRV g1, Idexx $^{\circledR}$ ) no laboratório de Sanidade, setor de virologia da Embrapa Suínos e Aves, Concórdia, SC. Os exames sorológicos dos suínos não vacinados foram realizados no laboratório CEDISA (Centro de Diagnóstico em Saúde Animal, Concórdia, SC) com o teste de Elisa de triagem (HerdChek PRV-Screening, Idexx ${ }^{\circledR}$ ), que detecta anticorpos para a glicoproteína B ou gB. Os soros positivos neste teste foram também testados por soroneutralização, conforme descrita anteriormente (ROMERO et al., 1986). Os testes de Elisa comerciais foram realizados conforme recomendações do fabricante (Idexx $\left.{ }^{\circledR}\right)$.

Amostras de cérebro de leitões com suspeita clínica de DA foram encaminhadas ao laboratório CEDISA para isolamento viral do VDA em células de cultivo laboratorial SK-6 (rim de suíno), conforme metodologia descrita anteriormente e usada na rotina deste laboratório (ROWE \& ROMERO, 1986).

Para realização do diagnóstico diferencial de DNA latente do VDA por reação da polimerase em cadeia (PCR), amostras de DNA extraído de gânglio trigeminal ou de amígdala de suíno positivo no teste de ELISA oriundos de plantel vacinado foram testados por PCR. Amostras de DNA dos órgãos foram obtidas pelo método da proteinase $\mathrm{K}$ conforme descrito anteriormente (SAMBROOK et al., 1989). As seqüências dos primers aneladores de glicoproteínas virais gD e gE para o VDA utilizados e os testes de PCR foram realizadas como descrito por SCHANG \& OSÓRIO (1993). O diagnóstico de infecções latentes por PCR determina que a não-amplificação da seqüência da gE (gE-) e a amplificação da gD (gD+) 
corresponde a suínos vacinados com vacina viva atenuada (gD+/gE-) e não com suínos infectados por vírus de campo. Os suínos infectados por vírus de campo são aqueles em que a PCR resulta gD+/gE+ (o vírus de campo apresenta a gE, ao contrário das cepas vacinais Bartha ou Begonia (gE-), utilizadas para a produção de vacinas com vírus vivo modificado). Enfim, se os animais não estão infectados com vírus de campo, nem vacinados com vacina viva atenuada, serão gD-/gE- (VAN OIRSCHOT et al., 1990; METTENLEITER, 2000).

Procedimentos adotados nos rebanhos infectados: Logo após o diagnóstico da doença, foi instituído um programa de vacinação do plantel contra a DA com vacina inativada e deletada para gE (Geskypur ${ }^{\circledR}$ Merial), conforme a orientação dos fabricantes e, passados os sinais clínicos, os rebanhos foram despovoados, conforme recomendações do Programa Estadual de Erradicação da DA (MORÉS \& ZANELLA, 2003). Estes procedimentos também foram adotados nos rebanhos que manifestaram sinais clínicos da DA (foco) ou que apresentaram alta prevalência sorológica (maior que 10\%) para o VDA (protocolo de despovoamento total). Os rebanhos que apresentaram prevalência sorológica para o VDA igual ou menor que $10 \%$ foram incluídos no protocolo de erradicação da DA por sorologia diferencial. Este protocolo consistiu na vacinação contra a DA de todos os reprodutores e nos exames sorológicos a cada 60 dias, em $100 \%$ dos reprodutores, com imediata eliminação dos positivos. Nos rebanhos de ciclo completo, além da sorologia dos reprodutores, foi realizada também sorologia por amostragem nos suínos de terminação com mais de $60 \mathrm{~kg}$. As granjas somente foram consideradas livres da infecção pelo VDA após duas sorologias consecutivas negativas em $100 \%$ dos reprodutores e na amostragem de suínos da terminação, no caso de granjas de ciclo completo, seguidas de duas monitorias por amostragem, também negativas, realizadas a cada 6 meses. O cálculo da amostragem segue as recomendações do programa, considerando uma prevalência estimada de $5 \%$ e um grau de confiança de 95\% (ZANELLA \& MORÉS, 2001).

Histórico e descrição do problema:

Caso 1: Granja 1 - ADA foi identificada pela primeira vez na propriedade em outubro de 2002, apresentando sinais clínicos e uma prevalência sorológica de $73,3 \%$ e foi encaminhada para despovoamento, conforme preconiza o programa. Posteriormente, em fevereiro de 2003, a granja foi repovoada, segundo informações do produtor, com suínos não-certificados da granja 2 (veja a seguir). $\mathrm{Na}$ região perifocal à granja 1 , havia outras três granjas que apresentaram exame sorológico negativo, mas, por precaução, recomendou-se o uso da vacina para DA.

Em dezembro de 2003, na sorologia por amostragem realizada durante o repovoamento, foram testadas 33 amostras. Destas amostras testadas, duas apresentaram resultado soropositivo, correspondendo a $6,1 \%$. A partir desse resultado, foi recomendada a vacinação oficial nos reprodutores e nos leitões, e a granja foi encaminhada para erradicação por sorologia. Na primeira coleta de $100 \%$ do plantel, totalizando 156 amostras de soro, 18 animais resultaram soropositivos $(11,5 \%)$. Pelas informações contidas no formulário de coleta de soro, a recomendação de vacinação oficial do plantel e dos leitões não foi acatada pelo produtor. Esta granja foi então interditada, o plantel foi vacinado oficialmente e encaminhado para erradicação por sorologia. A figura 1 apresenta um fluxograma de movimento de suínos com a descrição do problema enfocado neste estudo.

Caso 2: Granjas 2 a 13 - A granja 2 com 469 matrizes não possuía certificação sanitária e pertence a um mini-integrador que produzia e comercializava fêmeas F1 ilegalmente para reposição de 40 rebanhos UPL integrados, totalizando cerca de 2.000 matrizes. Como o proprietário da granja 1 obteve fêmeas não certificadas da granja 2, uma amostragem sorológica para DA foi realizada nesta granja (granja 2). De 51 amostras testadas, 39 foram positivas para a DA, correspondendo a 76,5\%. A granja 2 foi interditada, os soros dos suínos foram colhidos por amostragem em todas as UPLs de sua mini-integração e um questionário de rastreabilidade foi aplicado. A granja 2 foi despovoada conforme o protocolo do programa e todas as granjas da mini-integração foram vacinadas. Na sorologia das 40 granjas UPLs integradas, 12 resultaram soropositivas e 11 entraram no programa de erradicação por sorologia (granjas 3 a 13). A granja 14 apresentou sorologia positiva em 22,8\% das amostras testadas e foi despovoada. As demais 28 granjas foram negativas, e continuam em monitoramento sorológico, portanto, não serão descritas aqui.

Caso 3: Granjas 15 a 21 - Todas pertencem ao mesmo proprietário, sendo que as granjas 15 a 20 são integradas a uma empresa, e a 21 é independente. Devido à proximidade da granja 15 à granja 2, uma sorologia por amostragem foi realizada e resultou positiva, com prevalência em 96\%. A granja 15 foi despovoada e todas as granjas deste proprietário (granjas 15 a 21) foram testadas sorologicamente. Além da granja 15, as granjas 18, 19, 20 e 21 também apresentaram resultados sorológicos positivos para VDA. Destas, as granjas 18 e 21 resultaram positivas com elevada soroprevalência e foram despovoadas. A granja 20 apresentou baixa prevalência e foi encaminhada para seguir o protocolo de erradicação 


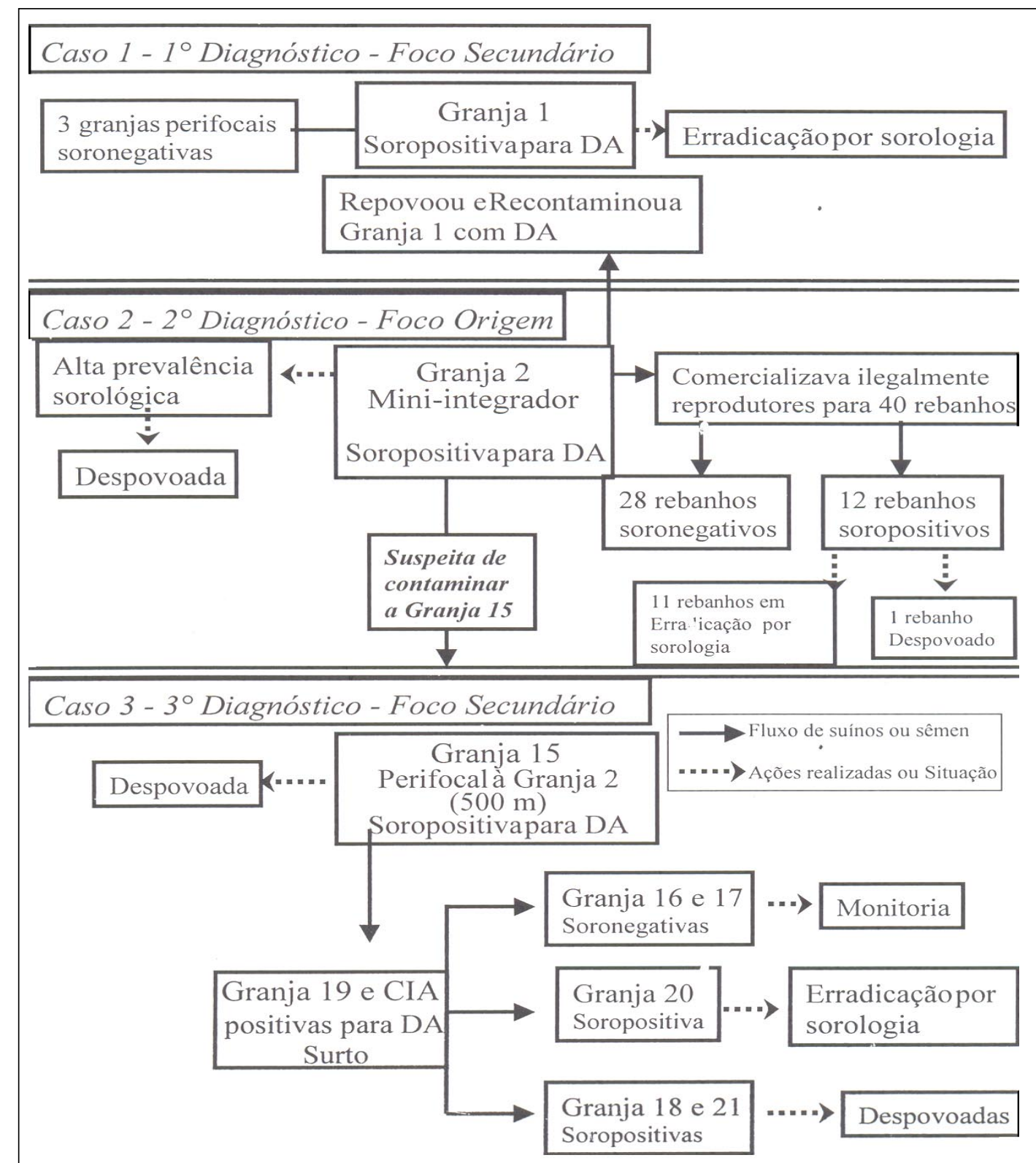

Figura 1 - Histórico, descrição do problema, fluxo de suínos ou de sêmen, ações realizadas e situação.

por sorologia. A granja 19 foi vacinada e também incluída no programa de erradicação por sorologia. Porém, dias após a amostragem, ela apresentou sinais clínicos (aborto, mortalidade de leitões e de gatos). Um leitão foi enviado para isolamento viral e o resultado foi positivo para o VDA. A granja foi interditada e despovoada imediatamente após a confirmação do isolamento viral. Na mesma granja, funcionava uma central de inseminação artificial (CIA) não-certificada com 13 machos alojados, em que o sêmen coletado era usado nos plantéis das granjas 15 a 21. Devido ao risco do sêmen estar contaminado com o VDA e infectar as outras granjas do proprietário, todos os cachaços da central foram testados sorologicamente e enviados ao abate. Os plantéis das granjas 16 e 17 resultaram soronegativos, porém, foram vacinados e monitorados periodicamente.

\section{RESULTADOS E DISCUSSÃO}

O relato da disseminação da infecção pelo VDA para os rebanhos envolvidos neste estudo estão na figura 1 . No período investigado, pelo menos 48 granjas compraram suínos das granjas 2 ou receberam 
sêmen de cachaços da granja 19. A granja 2 distribuiu reprodutores suínos não certificados para 41 UPLs e, das quais, 13 (31,7\%) (granjas 1, 3-14) receberam pelo menos um animal com sorologia positiva para o VDA. Os demais $28(68,3 \%)$ rebanhos não foram contaminados pelo VDA, pois apresentaram sorologia negativa e se mantiveram negativos durante a monitoria.

A granja 1 apresentou um animal positivo na sorologia, sendo que na primeira monitoria foi identificada como livre. A ocorrência de suínos reatores únicos deve ser investigada em rebanhos em programa de erradicação da DA (BASCUÑANA et al., 1997). O exame sorológico foi repetido e resultou negativo. Todavia, esse suíno reator único foi eutanasiado e amostras de gânglio trigeminal e de amígdala foram coletadas por veterinário oficial e enviadas para o laboratório de Sanidade, setor de virologia, da Embrapa Suínos e Aves. Análises por PCR foram realizadas utilizando primers para gD e gE de VDA. O teste de PCR do DNA extraído da amostra de gânglio trigeminal do suíno reator único da granja 1 foram negativos para o gene da gD do VDA ou gE (dados não apresentados). Assim, não se confirmou a infecção latente pelo vírus de campo (gE+/gD+), ou mesmo vacinal (gE+/gD-), caso o produtor tivesse vacinado os reprodutores com a vacina viva atenuada. A vacina viva atenuada para VDA pode ser utilizada em SC, único estado brasileiro com controle oficial da DA, somente sob supervisão do veterinário oficial, e em suínos destinados ao abate. Para reprodutores é permitida a aplicação da vacina inativada deletada para gE. Todos os reprodutores suínos restantes foram coletados e apresentaram resultado negativo, portanto esta monitoria foi considerada como a primeira negativa. A segunda monitoria foi realizada e apresentou resultado negativo. Hoje a granja encontra-se definitivamente livre.

Apesar da distribuição do VDA na miniintegração a partir da granja 2, a situação atual está sob controle. Os resultados dos exames sorológicos dos suínos das 12 granjas UPLs (granjas 3 a 14) integrados do proprietário da granja 2 indicaram que todas as granjas apresentaram sorologias 100\% negativas. Além disso, as duas monitorias por amostragem obtiveram resultado negativo, sendo que todas foram consideradas definitivamente livres. A granja 8 estava erradicando por sorologia, porém, o proprietário decidiu eliminar o plantel. Atualmente a granja está terminando leitões e apresentou a última monitoria livre. A granja 14 (despovoada) foi repovoada e apresentou resultado negativo nas duas monitorias pós-repovoamento, sendo também considerada como definitivamente livre.

Ainda não está claro como e quando a infecção por VDA iniciou nas granjas 15 e 18-21, como descrito no caso 3. Sabe-se da proximidade da granja 15 com a granja 2 (aproximadamente $500 \mathrm{~m}$ ) e da distribuição de sêmen suíno da granja 19 para as granjas 15 - 21. Graças ao sistema de rastreabilidade do programa de erradicação, descobriu-se que uma das granjas deste proprietário (granja 15) estava com soroprevalência elevada para o VDA, mas sem apresentar sinais clínicos. A partir deste resultado, os outros plantéis foram testados e medidas de controle e erradicação do VDA foram tomadas. Todavia, isso não evitou que, na granja 19, a infecção pelo VDA recrudescesse e aparecesse a doença clínica com mortalidade de leitões e isolamento viral. Efeito citopático positivo para VDA foi detectado 36 horas após a inoculação em células SK-6 com a suspensão de cérebro de leitões doentes. As granjas 15, 16, 18, 19 e 20 foram repovoadas e já apresentaram duas monitorias pós repovoamento negativas e encontramse atualmente definitivamente livres. A granja 21 também apresentou a primeira monitoria pósrepovoamento negativa, porém o proprietário decidiu fechar a granja. Os resultados dos exames sorológicos da segunda monitoria da granja 17 indicaram um animal reator único e foi encaminhada para erradicação por sorologia. Atualmente ela encontra-se com a primeira monitoria negativa e aguarda prazo para realização da segunda para se tornar livre.

É importante ressaltar o potencial de disseminação do VDA a partir de granjas que comercializam ilegalmente suínos de reposição (MAES et al., 1983). Esta é a principal razão para praticar a reposição do plantel apenas com suínos de granjas GRSC (granja de reprodutores suínos certificadas), que são sanitariamente certificadas pelo MAPA por seis meses, conforme a IN-19. Neste episódio, caso não fossem tomadas medidas de erradicação da DA, a granja 2 provavelmente continuaria a distribuição de suínos soropositivos na forma latente para seus integrados e possivelmente para outros produtores, disseminando o VDA na região. Isso certamente afetaria o mercado exportador e os índices de produtividade do estado. Com as medidas de erradicação tomadas, o problema aparentemente se limitou às 19 granjas identificadas positivas. Atualmente a granja 2 é uma granja certificada, monitorada semestralmente conforme a IN-19 do MAPA, e comercializa reprodutores legalmente.

Devido à capacidade do VDA de estabelecer infecção latente nos suínos, sem o aparecimento de sinais clínicos, o suíno aparentemente não-infectado é um disseminador potencial do vírus (DAVIES \& BERAN, 1980; MAES et al., 1983). Por esse e outros motivos, torna-se cada vez mais importante que os suinocultores exijam a certificação sanitária oficial dos 
rebanhos que fornecem reprodutores para a sua criação. Também foi observado que esta mini-integração, assim como outras em SC, não possuem um veterinário responsável. Esse profissional deve elaborar os programas sanitários para a empresa e seus integrados. Apesar da importância, ainda falta uma legislação específica para isso.

Sabe-se que a introdução de leitões ou de reprodutores, cujo estado sanitário é desconhecido, é a principal origem de focos da DA em rebanhos isolados (ANDERSON et al., 1990). No entanto, curtas distâncias e os vetores clássicos de contaminação como visitas, banhos, caminhões, dejetos, dentre outros, também devem ser considerados como risco de transmissão do VDA (DAVIES \& BERAN, 1981). Em regiões de alta densidade de suínos, onde a infecção pelo VDA é elevada, correntes de ar também podem transmitir o VDA de um rebanho para outro. As três granjas no perifoco da granja 1 não se infectaram provavelmente porque começaram a vacinar logo após a confirmação da DA na granja 1 . Naqueles rebanhos que, apesar de terem recebido suínos de rebanhos positivos, resultaram negativos, a infecção não foi transmitida provavelmente porque os animais adquiridos não estavam infectados.

Como recomendação, os produtores de suínos em ciclo completo ou UPL jamais devem adquirir suínos de reposição ou outro qualquer de granjas que não tenham a certificação sanitária emitida pelo MAPA e devem observar a validade de seis meses no documento de certificação. A distribuição ou o comércio de suínos de reposição sem a certificação sanitária oficial pode ocorrer principalmente em miniintegrações. Sugere-se maior fiscalização e que todas as integrações de suínos tenham um veterinário responsável sanitário que garanta o fluxo de animais entre os rebanhos, como forma de reduzir a disseminação de doenças.

\section{REFERÊNCIAS}

ANDERSON, P.L. et al. Factors associated with circulation of pseudorabies virus within swine herds. Journal of the American Veterinary Medical Association, v.196, n.6, p.877-880, 1990.

BASCUNANA C.R. et. al. Detection of psudorabies virus genomic sequences in apparently uninfected 'single reactor' pigs. Veterinary Microbiology, v.55, p.37-47, 1997.

DAVIES, E.B.; BERAN, G.W. Spontaneous shedding of pseudorabies virus from clinically recovered postparturient sow. Journal of the American Veterinary Medical Association, v.176, p.1345-1347, 1980.

DAVIES, E.B.; BERAN, G.W. Influence of environmental factors upon the survival of Aujeszky's disease virus. Research in Veterinary Science, v.31, p.32-36, 1981.
KLUGE, J.P. et al. Pseudorabies (Aujeszky's disease). In: LEMAN, A.D. et al. Diseases of swine. 7.ed. Ames: Iowa State University, 1992. cap.24, p.312-323.

MAES, P. K. et. al. Shedding patterns in swine of virulente and attenuated pseudorabies virus. American Journal of Veterinary Research, v.44, n.11, p.2083-2086, 1983.

METTENLEITER, T.C. Aujeszky's disease (pseudorabies) virus: the virus and molecular pathogenesis-state of the art. Veterinary Record, v.31, p.99-115, 2000.

MORÉS, N.; ZANELLA, J.R.C. Programa de erradicação da doença de Aujeszky em Santa Catarina. Concórdia: Embrapa Suínos e Aves, 2003. 50p. (Embrapa Suínos e Aves. Documentos, 81).

MORÉS, N. et al. Programa de erradicação da doença de Aujeszky no Estado de Santa Catarina. Concórdia: Embrapa Suínos e Aves, 2005. 8p. (Circular técnica, 44).

OFFICE INTERNATIONAL DES EPIZOOTIES (OIE): World organization for animal health. Animal Disease Data: diseases notifiable to the OIE. Capturado em: 28 abr. 2006. On line. Disponível na Internet: <http://www.oie.int>.

ROIZMAN, B. Herpesviridae: a brief introduction. In: FIELDS, B.N. et al. Fundamental virology. 2.ed. Nw Iork: Raven, 1990. cap.33, p.841-848.

ROMERO, C.H. et al. Erradicação do vírus da doença de Aujeszky de plantéis de reprodutores suínos através da testagem e eliminação de suínos com anticorpos. Pesquisa Veterinária Brasileira, v.6, p.1-4, 1986.

ROWE, C.A.; ROMERO, C.H. Isolamento e identificação do vírus da doença de Aujeszky de surtos em suínos no Estado de Santa Catarina. Pesquisa Veterinária Brasileira, v.6, p.99103, 1986.

SAMBROOK J. et. al. Molecular cloning: a laboratory manual. 2.ed. New York: Cold Spring Harbor Laboratory, 1989. 545p.

SCHANG, L.M.; OSORIO, F.A. A quantitative technique for the study of the latency of Aujeszky Virus. Revue Scientifique et Technique de l' Office International des Epizooties, v.12, n.2, p.505-521, 1993.

VAN OIRSCHOT, J.T. et. al. Marker vaccines, virus proteinspecific, antibody assays and the control of Aujeszky's disease. Veterinary Microbiology, v.23, p.85-101, 1990.

ZANELlA, J.R.C.; MORÉS, N. Controle da doença de Aujeszky. Concórdia, SC: Embrapa Suínos e Aves, 2001. 8p. (Circular Técnica, 30).

ZANELLA, J.R.C. et. al. Estimativa de impacto econômico anual da doença de Aujeszky para a suinocultura da Estado de Santa Catarina. Concórdia: Embrapa Suínos e Aves, 2002. 4p. (Comunicado Técnico, 294). 